\section{To: (Receiving Organization) Distribution}

5. Proj./Prog./Dept./Div.:

Tank 241-TX-116
3. From: (Originating organization)

D. E. Place, SESC, H5-27 376-0176

6. Design Authority/ Design Agent/Cog. Engr.:
4. Related EDT No.:

NA

7. Purchase Order No.:

NA gm $8 / 25197$

11A. Design Baseline Document?

[] Yes

$[x]$ No

oonent No.:

NA

10. System/Bldg./Facility: NA

12. Major Assm. Dwg. No.:

NA

13. Permit/Permit Application No.:

NA

14. Required Response Date:

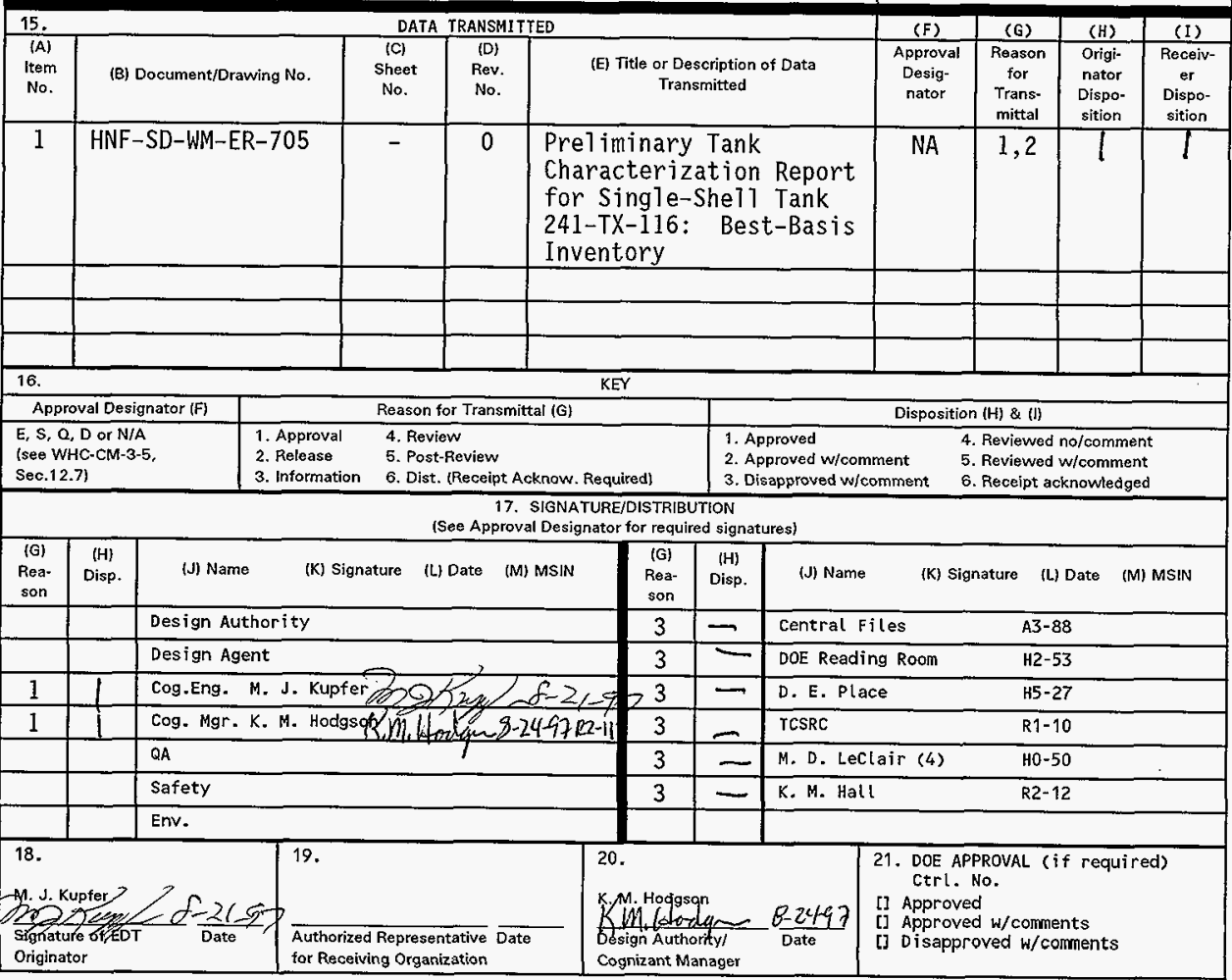




\title{
Preliminary Tank Characterization Report for Single-Shell Tank 241-TX-116: Best-Basis Inventory
}

\author{
D. E. Place
}

SGN Eurisys Services Corporation, Richland, WA 99352

U.S. Department of Energy Contract DE-AC06-96RL13200
EDT/ECN: 622651
UC: 712
Org Code: 74610
Charge Code:
N4G3A
3635
$9 m 8 / 25 / 97$
Tota1 Pages:

Key Words: TCR, best-basis inventory

Abstract: An effort is underway to provide waste inventory estimates that will serve as standard characterization source terms for the various waste management activities. As part of this effort, an evaluation of available information for single-she11 tank 24I-TX-116 was performed, and a best-bas is inventory was established. This work follows the methodology that was established by the standard inventory task.

TRADEMARK DISCLAIMER. Reference herein to any specific commercial product, process, or service by trade name, trademark, manufacturer, or otherwise, does not necessarily constitute or imply its endorsement, recomendation, or favoring by the United States Government or any agency thereof or its contractors or subcontractors.

Printed in the United States of America. To obtain copies of this document, contact: Document Control Services, P.O. Box 950, Mailstop H6-08, Richland WA 99352, Phone (509) 372-2420; Fax (509) 376-4989.
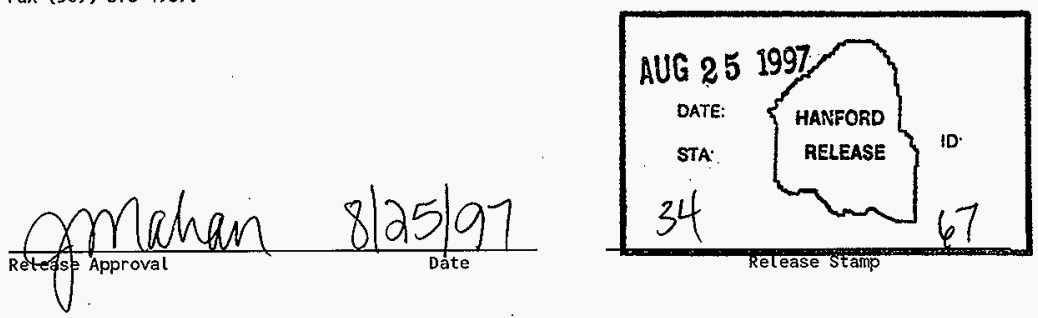

Approved for Public Release 


\title{
PRELIMINARY TANK CHARACTERIZATION REPORT FOR SINGLE-SHELL TANK 241-TX-116: BEST-BASIS INVENTORY
}

June 1997

\author{
D. E. Place \\ SGN Eurisys Services Corporation \\ Richland, Washington
}

Prepared for

U.S. Department of Energy

Richland, Washington 


\section{HNF-SD-WM-ER-705}

Revision 0

This page intentionally left blank. 


\section{PRELIMUNARY TANK CHARACTERIZATION REPORT \\ FOR SINGLE-SHELL TANK 241-TX-116: \\ BEST-BASIS INVENTORY}

This document is a preliminary Tank Characterization Report (TCR). It only contains the current best-basis inventory (Appendix D) for single-shell tank 241-TX-116. No TCRs have been previously issued for this tank, and current core sample analyses are not available. The best-basis inventory, therefore, is based on an engineering assessment of waste type, process flowsheet data, early sample data, and other available information.

The Standard Inventories of Chemicals and Radionuclides in Hanford Site Tank Wastes (Kupfer et al. 1997) describes standard methodology used to derive the tank-by-tank best-basis inventories. This preliminary TCR will be updated using this same methodology when additional data on tank contents become available.

\section{REFERENCE}

Kupfer, M. J., A. L. Boldt, B. A. Higley, K. M. Hodgson, L. W. Shelton, B. C. Simpson, and R. A. Watrous (LMHC), S. L. Lambert, and D. E. Place (SESC), R. M. Orme (NHC), G. L. Borsheim (Borsheim Associates), N. G. Colton (PNNL), M. D. LeClair (SAIC), R. T. Winward (Meier Associates), and W. W. Schulz (W²S Corporation), 1997, Standard Inventories of Chemicals and Radionuclides in Hanford Site Tank Wastes, HNF-SD-WM-TI-740, Rev. 0, Lockheed Martin Hanford Corporation, Richland, Washington. 
HNF-SD-WM-ER-705

Revision 0

This page intentionally left blank. 


\author{
HNF-SD-WM-ER-705 \\ Revision 0
}

\title{
APPENDIX D
}

\section{EVALUATION TO ESTABLISH BEST-BASIS INVENTORY FOR SINGLE-SHELL TANK 241-TX-116}


HNF-SD-WM-ER-705

Revision 0

This page intentionally left blank. 
HNF-SD-WM-ER-705

Revision 0

\section{APPENDIX D}

\section{EVALUATION TO ESTABLISH BEST-BASIS INVENTORY FOR SINGLE-SHELL TANK 241-TX-116}

An effort is underway to provide waste inventory estimates that will serve as standard characterization source terms for the various waste management activities (Hodgson and LeClair 1996). As part of this effort, an evaluation of available information for single-shell tank 241-TX-116 was performed, and a best-basis inventory was established. This work, detailed in the following sections, follows the methodology that was established by the standard inventory task.

\section{D1.0 CHEMICAL INFORMATION SOURCES}

Available chemical and radiological inventory estimates for tank 241-TX-116 consist only of the inventory estimate generated by the Hanford Defined Waste (HDW) model (Agnew et al. 1997a). No Tank Characterization Report (TCR) bas been previously issued for this tank, and recent core sample analyses are not available. The best-basis inventory, therefore, is primarily based on a 1976 core sample of the tank, augmented by radionuclide and chemical component data from the HDW model and from sample analyses of similar waste types.

\section{D2.0 COMPARISON OF COMPONENT INVENTORY VALUES}

The tank 241-TX-116 chemical and radionuclide inventory predicted by the HDW model (Agnew et al. 1997a) is provided in Table D2-1. The chemical species are reported without charge designation per the best-basis inventory convention. The HDW model inventory is based on $1,874 \mathrm{~kL}$ ( $495 \mathrm{kgal}$ ) of salt cake produced by the 242-T Evaporator and $257 \mathrm{~kL}$ (68 kgal) of diatomaceous earth.

Table D2-1. Hanford Defined Waste Model Prediction of Tank 241-TX-116 Inventory. (2 Sheets)

\begin{tabular}{|c|c|}
\hline Analyte & HDW model inventory ${ }^{\mathrm{a}}(\mathrm{kg})$ \\
\hline $\mathrm{Al}$ & 24,300 \\
\hline $\mathrm{Bi}$ & 4,140 \\
\hline $\mathrm{Ca}$ & 6,200 \\
\hline
\end{tabular}


HNF-SD-WM-ER-705

Revision 0

Table D2-1. Hanford Defined Waste Model Prediction of Tank 241-TX-116 Inventory. (2 Sheets)

\begin{tabular}{|c|c|}
\hline Analyte & HDW model inventory $(\mathrm{kg})$ \\
\hline $\mathrm{Cl}$ & 7,480 \\
\hline $\mathrm{CO}_{3}$ & 28,800 \\
\hline $\mathrm{Cr}$ & 3,630 \\
\hline $\mathrm{F}$ & 3,320 \\
\hline $\mathrm{Fe}$ & 10,200 \\
\hline $\mathrm{Hg}$ & 3.04 \\
\hline $\mathrm{K}$ & 1,960 \\
\hline $\mathrm{La}$ & $9.97 \mathrm{E}-05$ \\
\hline $\mathrm{Mn}$ & 99.2 \\
\hline $\mathrm{Na}$ & 628,000 \\
\hline $\mathrm{Ni}$ & 1,090 \\
\hline $\mathrm{NO}_{2}$ & 69,800 \\
\hline $\mathrm{NO}_{3}$ & 891,000 \\
\hline $\mathrm{OH}$ & 101,000 \\
\hline $\mathrm{Pb}$ & 181 \\
\hline $\mathrm{PO}_{4}$ & 157,000 \\
\hline $\mathrm{Si}$ & 42,800 \\
\hline $\mathrm{SO}_{4}$ & 27,700 \\
\hline $\mathrm{Sr}$ & 0 \\
\hline TOC & 2,870 \\
\hline $\mathrm{U}$ & 22,300 \\
\hline $\mathrm{Zr}$ & 67.8 \\
\hline \multicolumn{2}{|l|}{ Radionuclide $^{b}$ (Ci) } \\
\hline${ }^{137} \mathrm{Cs}$ & 247,000 \\
\hline${ }^{90} \mathrm{Sr}$ & 66,000 \\
\hline
\end{tabular}

HDW = Hanford Defined Waste

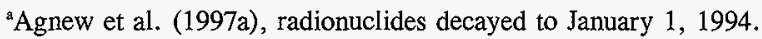

${ }^{\mathrm{b}}$ Revision 4 of the Hanford Defined Waste (HDW) model (Agnew et al. 1997a) contains estimates for 46 radionuclides. Only the two most prevalent, ${ }^{90} \mathrm{Sr}$ and ${ }^{137} \mathrm{Cs}$, are listed in this table. The HDW model radionuclide predictions are baselined to January 1, 1994. 
HNF-SD-WM-ER-705

Revision 0

\section{D3.0 COMPONENT INVENTORY EVALUATION}

\section{D3.1 CONTRIBUTNNG WASTE TYPES}

The HDW model (Agnew et al. 1997a), the Sort on Radioactive Waste Type (SORWT) model (Hill et al. 1995) and the waste tank summary report (Hanlon 1997) are consistent as to the waste types present in tank 241-TX-116, but not total waste volume.

The HDW model (Agnew et al. 1997a) refers to 242-T Evaporator salt cakes formed during 1951 to 1955 as T1 SltCK. The HDW model refers to 242-T Evaporator salt cakes or slurries formed from 1965 to 1976 as T2 SltCk on a global basis, or SMMT2 when calculated for an individual tank by the Supernatant Mixing Model (SMM).

The HDW model (Agnew et al. 1997a) predicts that the tank contains 1,223 kL (323 kgal) of defined waste T1 SltCk, $651 \mathrm{~kL}$ (172 kgal) of SMMT2 salt slurry predicted from the Supernatant Mixing Model, and $257 \mathrm{~kL}$ (68 kgal) of added diatomaceous earth. The total waste volume predicted by the HDW model is $2,131 \mathrm{~kL}$ (563 kgal). The volume of SMMT2 waste predicted by the HDW model Revision 4 (Agnew et al. 1997a) was reduced by $257 \mathrm{~kL}$ ( $68 \mathrm{kgal}$ ) from the HDW revision 3 tank layer model estimate (Agnew et al. 1996), creating a total waste volume mismatch with the waste tank summary (Hanlon 1997) and the SORWT model (Hill et al. 1995).

The SORWT model (Hill et al. 1995) lists EB (evaporator bottoms) and 1C (first cycle $\mathrm{BiPO}_{4}$ waste) as the primary and secondary waste types, respectively, but credits the entire tank 241-TX-116 volume (2,388 kL [631 kgal]) to salt cake with $87 \mathrm{~kL}$ (23 kgal) of interstitial liquid. Hanlon (1997) also indicates that the entire tank inventory is salt cake, with volumes identical to the SORWT model.

\section{D3.2 EVALUATION OF TECHNICAL FLOWSHEET INFORMATION}

Waste transaction records (Agnew et al. 1997b) show that tank 241-TX-116 was the first evaporator bottoms receiving tank for the 242-T Evaporator. Tank 241-TX-116 received $10,167 \mathrm{~kL}(2,686 \mathrm{kgal})$ of evaporator bottoms between the second quarter of 1951 and the second quarter of 1954. The deposition of a salt cake layer in tank 241-TX-116 would be expected. Salt cake supernatants were recycled to the 242-T Evaporator via tank 241-TX-118 or transferred to tanks 241-TY-101 or 241-TX-117.

The SORWT model (Hill et al. 1995) inclusion of 1C waste as a secondary waste type is somewhat misleading. Waste transaction records (Agnew et al. 1997b) and waste status summaries (Anderson 1990) show that $T$ Plant 1C wastes were never routed directly to tank 241-TX-116. An Anderson (1990) entry for the fourth quarter of 1953 indicates that tank 241-TX-116 was the active tank for $1 \mathrm{C}$ and tributyl phosphate (TBP) bottoms. Tank 
HNF-SD-WM-ER-705

Revision 0

241-TX-116 received evaporator concentrated supernatants from these wastes, but $1 \mathrm{C}$ sludges were not introduced into the tank.

Tank 241-TX-116 again received concentrated evaporator bottoms from the 242-T Evaporator and recycled supernatants to the evaporator beginning in the fourth quarter of 1965 and continuing intermittently until the third quarter of 1972 (Agnew et al. 1997b). Anderson (1990) reports that these operations occurred between the fourth quarter of 1965 and the first quarter of 1972 . A total of $22,839 \mathrm{~kL}(6,034 \mathrm{kgal})$ of concentrated salt solutions were routed to tank 241-TX-116. Salt cake would have formed as the concentrated salt solutions cooled and a large salt cake layer would have been deposited on top of previously existing salt cake.

Seven truck loads of diatomaceous earth (approximately 95.3 MT) were added to the tank in November 1970 (Buckingham and Metz 1974). The diatomaceous earth, consisting primarily of silicon dioxide, was added to demonstrate liquid immobilization using a absorbent solid.

Supernatant remaining in tank 241-TX-116 was transferred to tank 241-TX-113 in the fourth quarter of 1972 (Agnew et al. 1997b). Salt well pumping of the interstitial liquid occurred between 1982 and 1984.

\section{D3.3 DETERMINATION OF WASTE VOLUMES}

The HDW model estimates the T1 salt cake volume based on a solids volume measurement made in the first quarter of $1965(1,223 \mathrm{~kL}$ [323 kgall]). A total of $10,167 \mathrm{~kL}$ (2,686 kgal) of 242-T evaporator bottoms were transferred to tank 241-TX-116, which is considered sufficient to have produced the observed volume of T1 SltCk.

The HDW volume of T2 salt cake is based on the $2,131 \mathrm{~kL}$ ( $563 \mathrm{kgal}$ ) final volume of solids determined from an October 1992 manual tape measurement (Husa et. al. 1993). The HDW model predicts a $651 \mathrm{~kL}(172 \mathrm{kgal}) \mathrm{T} 2$ salt cake inventory based on the difference in volumes and allowing $257 \mathrm{~kL}$ ( $68 \mathrm{kgal}$ ) for the added diatomaceous earth. The volume of T2 salt cake layer would be $908 \mathrm{~kL}$ (240 kgal) using the Hanlon (1997) total waste volume of $2,388 \mathrm{~kL}(631 \mathrm{kgal})$.

Hanlon (1997) bases the 2,388 kL (631 kgal) total waste volume on a March 31, 1972, measurement. Discrepancies between the manual tape measurements and the Hanlon (1997) single-shell tank (SST) waste inventories have been evaluated (Swaney 1993). For tank 241-TX-116, Swaney (1993) concludes that the manual tape measurement is being made at a location where the waste has slumped towards the salt screen and that no adjustments to the Hanlon (1997) volume was required. Examination of an October 17, 1989, photograph of the tank 241-TX-116 interior (Brevick et al. 1997) shows a dark spot on the waste surface at the manual tape location, indicating that the plummet may have created a bole in the waste surface, which would further reduce the measured volume. The waste volume in tank 


\section{Revision 0}

241-TX-116 has been reduced by salt well pumping as indicated by the waste slumping, but the manual tape readings appear to significantly understate the waste inventory. The Hanlon (1997) total waste volume of $2,388 \mathrm{~kL}$ (631 kgal) should be used for inventory determinations.

The HDW model assumes a density of $0.39 \mathrm{~g} / \mathrm{mL}$ for diatomaceous earth. This is roughly the equivalent of the $24 \mathrm{lbs} / \mathrm{cubic}$ foot as-delivered packed density reported by the vendor (Buckingham and Metz 1974). However, the HDW model makes no provision for absorption of liquid waste by the diatomaceous earth.

An alternate estimate of the volume occupied by diatomaceous earth can be made as follows:

Assumptions:

1. $1.85 \mathrm{~mL}$ waste absorbed per $\mathrm{g}$ diatomaceous earth (range $1.1-2.6 \mathrm{~mL} / \mathrm{g}$, Buckingham and Metz 1974).

2. $\quad 1.4 \mathrm{~g} / \mathrm{mL}$ solution density (saturated salt solution)

3. $\quad 1.7 \mathrm{~g} / \mathrm{mL}$ final density (wet clay, Perry and Chilton 1973)

4. $95.3 \mathrm{MT}$ diatomaceous earth added

\section{Calculation:}

Final volume $=[$ (waste absorption $\mathrm{x}$ solution density + basis weight diatomaceous earth)]/final waste density $\mathrm{x}$ total mass diatomaceous earth

Final volume $=\{[(1.85 \mathrm{ml}$ waste $/ \mathrm{gDE} \times 1.4 \mathrm{~g}$ waste $/ \mathrm{ml})+1 \mathrm{gDE}] /(1.7 \mathrm{~g} / \mathrm{ml}) \times$ $95.3 \mathrm{E}+06 \mathrm{gDE}\} / 3785 \mathrm{ml} / \mathrm{gal}$

Final volume $=53,200 \mathrm{gal}(201 \mathrm{~kL})$

Based on this alternate calculation, the HDW model assumed volume for the diatomaceous earth is reasonable. The diatomaceous earth has been dispersed in the tank 241-TX-116 waste as indicated by the silicon analyses for the 1976 core sample (Horton 1977), and does not exist as a discrete waste layer. However, the diatomaceous earth could be assumed to displace the $257 \mathrm{~kL}$ ( $68 \mathrm{kgal}$ ) predicted by the HDW model for inventory determination purposes. 
HNF-SD-WM-ER-705

Revision 0

\section{D3.4 COMPOSITION OF TANK 241-TX-116 WASTE}

\section{D3.4.1 Composition of T1 Salt Cake}

Operation of the 242-T Evaporator between 1951 and 1955 resulted in 2,903 kL ( $767 \mathrm{kgal}$ ) of salt cake that is contained in 10 underground storage tanks in the T, TX, and TY Tank Farms (Agnew et al. 1997a). The evaporator feeds during this time period consisted largely of $\mathrm{IC}$ and TBP waste supernatants. The HDW model refers to this salt cake as T1 SltCk on a global basis. The HDW model uses this average T1 SltCk composition to calculate the $T 1$ salt cake inventories for individual tanks rather than its SMM because of the lack of detailed evaporator feed composition data. The salt cake produced by the 242-T Evaporator from 1951 through 1955 will be referred to as $\mathrm{T} 1$ salt cake hereafter in this report. Seventy-nine percent of the T1 salt cake is contained in the TX Tank Farm. With the exception of tank 241-T-109, all tanks containing T1 salt cake also contain other waste types. Five of the tanks containing $\mathrm{T} 1$ salt cake have been core or auger sampled (tanks 241-T-108, 241-T-109, 241-TX-116, 241-TY-101, and 241-TY-102).

The auger samples for tanks $241-\mathrm{T}-108$ and $241-\mathrm{T}-109$ are recent (1995) and laboratory analyses should meet all Hanford Federal Facility Agreement and Consent Order (Tri-Party Agreement) (Ecology et al. 1994) requirements. Tank 241-T-108 is expected to contain 1C/CW sludge as well as T1 sait cake (Agnew et al. 1997a); however, the analytical results indicate that the tank 241-T-108 sample retrieved was primarily salt cake as evidenced by the high sodium concentration $(223,000 \mu \mathrm{g} / \mathrm{g}$ ) reported for the composite sample (Baldwin et al. 1996). Tank 241-T-109 contains only T1 salt cake generated from the 242-T Evaporator concentration of TBP and $1 \mathrm{C} / \mathrm{CW}$ supernatants. The composition of the tank 241-T-109 salt cake is somewhat unusual in that it is primarily sodium phosphate rather than sodium nitrate. The composition reported by the TCRs for tank 241-T-108 (Baldwin et al. 1996) and for tank 241-T-109 (Brown et al. 1996) are included in Table D3-1.

T1 salt cake was deposited in tank 241-TX-116 between 1951 and 1955 . The tank 241-TX-116 core sample was taken with the initial prototype of a rotary core sampler between April 1976 and January 1977 (Allen 1977). Sample recoveries were relatively poor and no material was recovered from several segments. Additionally, analytical methods and quality assurance differed from current practices. The analytical data are provided in a letter report (Horton 1977). Core segments 6, 7,9, and 10 are expected to be $T 1$ salt cake based on the HDW model layer volumes, and this is confirmed by differences in the core sample results as compared to segments 1 through 4 (T2 salt cake). No material was recovered in segments 5 and 8, nor for any segment below segment 10 (the bottom $307 \mathrm{~kL}$ [81 kgal] of waste).

Tanks 241-TY-101 and 241-TY-102 were core sampled in 1985. As with the tank 241-TX-116 core sample, the analytical methods and quality assurance differed from current practices. Tank 241-TY-101 contains ferrocyanide scavenging wastes as well as salt cake. The relatively low sodium concentration reported for the composite $(121,000 \mu \mathrm{g} / \mathrm{g}$, Weiss 
and Mauss 1987a) indicates that the sample was primarily sludge and that the data are not usable as an example of $\mathrm{T} 1$ salt cake. Tank $241-\mathrm{TY}-102$ contains both $\mathrm{T} 1$ and $\mathrm{T} 2$ salt cakes (about 45 percent T1 salt cake). Since only composite analyses were performed, the data are not appropriate examples of $\mathrm{T} 1$ salt cake.

However, it should be noted that the phosphate concentration for tank $241-\mathrm{TY}-102$ is relatively low $(29,000 \mu \mathrm{g} / \mathrm{g}$, Weiss and Mauss $1987 \mathrm{~b})$, indicating that the phosphate concentration of the T1 salt cake added to tank 241-TY-102 could not have been comparable to concentrations measured for tanks 241-T-108 and 241-T-109 (125,000 and 246,000 $\mu \mathrm{g} / \mathrm{g}$, respectively, Table D3-1). Phosphate concentrations exceeding $100,000 \mu \mathrm{g} / \mathrm{g}$ are not necessarily typical of T1 salt cakes based on the analytical results for tanks 241-TY-102 and 241-TX-116. The reason for this wide variation in phosphate concentration is not known, but supernatants recycled from salt receiving tanks to the 242-T Evaporator might have been depleted in phosphate, and consequently the salt cakes formed from recycled supernatants would have a lower phosphate concentration.

The analytical data for tanks $241-\mathrm{T}-108,241-\mathrm{T}-109$, and $241-\mathrm{TX}-116$ are tabulated in Table D3-1. The relative standard deviation of the mean for all components except sodium and zirconium are extremely high, indicating that the composition of the waste type is extremely variable. Any model which assumes that T1 salt cake has a relatively consistent composition, including the prediction in Table D3-1 or the HDW model (Agnew et al. 1997a), will have very limited usefulness in predicting the inventory of a tank containing T1 salt cake. The predicted T1 salt cake composition differs significantly from the HDW model T1 SltCk concentrations for most chemical analytes. Due to the extreme variability between $\mathrm{T} 1$ salt cakes, the tank 241-TX-116 sample concentration data will be used for the inventory determination when data are available. Average analyte concentration data from tanks 241-T-108 and 241-T-109 will be used for analyses that were not performed on the tank 241-TX-116 samples. The composition predicted by the HDW model for the global composition of T1 salt cake is included in Table D3-1 for comparison.

Table D3-1. Composition of T1 Salt Cakes (3 Sheets).

\begin{tabular}{|c|c|c|c|c|c|c|}
\hline Analyte & $\begin{array}{c}\text { Tank } \\
241-\mathrm{T}-108^{\mathrm{a}} \\
(\mu \mathrm{g} / \mathrm{g})\end{array}$ & $\begin{array}{c}\text { Tank } \\
241-\mathrm{T}-109^{\mathrm{b}} \\
(\mu \mathrm{g} / \mathrm{g})\end{array}$ & $\begin{array}{c}\text { Tank } \\
241-\mathrm{TX}-116^{\mathrm{c}} \\
(\mu \mathrm{g} / \mathrm{g})\end{array}$ & $\begin{array}{c}\text { Relative } \\
\text { std dev } \\
\text { of mean } \\
(\%)\end{array}$ & $\begin{array}{c}\text { Predicted } \\
\text { T1 salt } \\
241-\mathrm{TX}-116 \\
\text { layer }(\mu \mathrm{g} / \mathrm{g})\end{array}$ & $\begin{array}{c}\text { HDW } \\
\text { model } \\
\text { T1 } \\
\left(\mu \mathrm{g} / \mathrm{g} / \mathrm{g}^{\mathrm{d}}\right)\end{array}$ \\
\hline $\mathrm{Ag}$ & $<7.96$ & 18.6 & $\mathrm{NR}$ & $\mathrm{NA}$ & $<13.3$ & $\mathrm{NR}$ \\
\hline $\mathrm{Al}$ & 2,290 & 1,250 & 1,720 & 17.2 & 1,720 & 140 \\
\hline $\mathrm{Bi}$ & 605 & 170 & $\mathrm{NR}$ & 56.1 & 388 & 1,807 \\
\hline $\mathrm{Ca}$ & 177 & 324 & $\mathrm{NR}$ & 29.3 & 251 & 2,117 \\
\hline $\mathrm{Cd}$ & $<7.96$ & $<5$ & $\mathrm{NR}$ & NA & $<5^{\mathrm{c}}$ & $\mathrm{NR}$ \\
\hline $\mathrm{Cl}$ & $<905$ & 341 & $\mathrm{NR}$ & NA & $341^{\mathrm{e}}$ & 1,377 \\
\hline
\end{tabular}


HNF-SD-WM-ER-705

Revision 0

Table D3-1. Composition of T1 Salt Cakes (3 Sheets).

\begin{tabular}{|c|c|c|c|c|c|c|}
\hline Analyte & $\begin{array}{c}\text { Tank } \\
241-\mathrm{T}-108^{\mathrm{a}} \\
(\mu \mathrm{g} / \mathrm{g})\end{array}$ & $\begin{array}{c}\text { Tank } \\
241-\mathrm{T}-109^{\mathrm{b}} \\
(\mu \mathrm{g} / \mathrm{g})\end{array}$ & $\begin{array}{c}\text { Tank } \\
241-\mathrm{TX}-116^{\circ} \\
(\mu \mathrm{g} / \mathrm{g})\end{array}$ & $\begin{array}{l}\text { Relative } \\
\text { std dev } \\
\text { of mean } \\
(\%)\end{array}$ & $\begin{array}{c}\text { Predicted } \\
\text { T1 salt } \\
241-\mathrm{TX}-116 \\
\text { layer }(\mu \mathrm{g} / \mathrm{g})\end{array}$ & $\begin{array}{c}\text { HDW } \\
\text { model } \\
\text { T1 SltCk } \\
(\mu \mathrm{g} / \mathrm{g})\end{array}$ \\
\hline $\mathrm{CO}_{3}$ & NR & 10,400 & 33,900 & 67.2 & 33,900 & 6,832 \\
\hline $\mathrm{Cr}$ & 19.2 & 40 & 150 & 58.3 & 150 & 129 \\
\hline $\mathrm{F}$ & 10,700 & 13,000 & 3,090 & 33.3 & 3,090 & 948 \\
\hline $\mathrm{Fe}$ & 6,110 & 5,490 & 16,000 & 37.0 & 16,000 & 4,041 \\
\hline $\mathrm{Hg}$ & NR & NR & NR & $\mathrm{NA}$ & $\mathrm{NA}$ & 0.601 \\
\hline $\mathrm{K}$ & $<239$ & $<500$ & NR & NA & $<239^{\circ}$ & 270 \\
\hline $\mathrm{La}$ & $<39.8$ & $<50$ & $\mathrm{NR}$ & NA & $<39.8^{\mathrm{e}}$ & 0 \\
\hline $\mathrm{Mn}$ & 182 & 1,030 & NR & 70.0 & 606 & 0 \\
\hline $\mathrm{Na}$ & 223,000 & 181,000 & 247,300 & 8.85 & 247,300 & 185,810 \\
\hline $\mathrm{Ni}$ & $<15.9$ & $<20$ & $\mathrm{NR}$ & $\mathrm{NA}$ & $<18$ & 396 \\
\hline $\mathrm{NO}_{2}$ & 6,210 & 492 & 200 & 84.8 & 200 & 5,526 \\
\hline $\mathrm{NO}_{3}$ & 392,000 & 20,800 & 575,300 & 49.5 & 575,300 & 333,726 \\
\hline $\mathrm{OH}$ & NR & NR & $\mathrm{NR}$ & $\mathrm{NA}$ & $\mathrm{NA}$ & 8,933 \\
\hline $\mathrm{Pb}$ & 533 & 303 & NR & 27.5 & 418 & 0 \\
\hline $\mathrm{P}$ as $\mathrm{PO}_{4}$ & 125,000 & 246,000 & 14,000 & 52.4 & 14,000 & 70,614 \\
\hline $\mathrm{Si}$ & 1,500 & 889 & 7,250 & 25.6 & 7,250 & 287 \\
\hline $\mathrm{S}$ as $\mathrm{SO}_{4}$ & 1,110 & 516 & 34,500 & 93.2 & 34,500 & 5,975 \\
\hline $\mathrm{Sr}$ & 21.6 & $<10$ & NR & $\mathrm{NA}$ & $<15.8$ & 0 \\
\hline TOC & NR & NR & NR & NA & NR & $1 \mathrm{E}-06$ \\
\hline $\mathrm{U}$ & 1,130 & $<500$ & 2.79 & $\mathrm{NA}$ & 2.79 & 6,140 \\
\hline $\mathrm{Zr}$ & 10.9 & 12.2 & NR & 5.63 & 11.6 & 19.2 \\
\hline $\begin{array}{l}\text { Radio- } \\
\text { nuclides }\end{array}$ & $\begin{array}{c}\text { Tank } \\
241-\mathrm{T}-108^{\mathrm{a}} \\
(\mu \mathrm{Ci} / \mathrm{g})\end{array}$ & $\begin{array}{c}\text { Tank } \\
241-\mathrm{T}-109^{\mathrm{b}} \\
(\mu \mathrm{Ci} / \mathrm{g})\end{array}$ & $\begin{array}{c}\text { Tank } \\
241-\mathrm{TX}-116^{\mathrm{c}} \\
(\mu \mathrm{Ci} / \mathrm{g})\end{array}$ & $\begin{array}{c}\text { Relative } \\
\text { std dev } \\
\text { of mean } \\
(\%)\end{array}$ & $\begin{array}{c}\text { Predicted } \\
\text { T1 salt layer } \\
(\mu \mathrm{Ci} / \mathrm{g})\end{array}$ & $\begin{array}{c}\text { HDW } \\
\text { model T1 } \\
\text { SltCk }^{d} \\
(\mu \mathrm{Ci} / \mathrm{g})\end{array}$ \\
\hline${ }^{241} \mathrm{Am}$ & $<0.123$ & $\mathrm{NR}$ & NR & NA & $<0.123^{f}$ & $4.67 \mathrm{E}-04$ \\
\hline${ }^{60} \mathrm{Co}$ & $<0.0162$ & $\mathrm{NR}$ & NR & NA & $<0.0162^{\mathrm{f}}$ & $5.77 \mathrm{E}-05$ \\
\hline${ }^{134} \mathrm{Cs}$ & $\mathrm{NR}$ & NR & 0.00781 & $\mathrm{NA}$ & $0.00781^{f}$ & $2.43 \mathrm{E}-06$ \\
\hline${ }^{137} \mathrm{Cs}$ & 2.06 & $\mathrm{NR}$ & 3.20 & 40.7 & $3.20^{\mathrm{f}}$ & 34.4 \\
\hline${ }^{154} \mathrm{Eu}$ & $<0.0514$ & $\mathrm{NR}$ & $\mathrm{NR}$ & $\mathrm{NA}$ & $<0.0514^{\mathrm{f}}$ & 0.00103 \\
\hline${ }^{155} \mathrm{Eu}$ & $<0.0503$ & NR & NR & $\mathrm{NA}$ & $<0.0503^{\mathrm{f}}$ & 0.00496 \\
\hline
\end{tabular}


HNF-SD-WM-ER-705

Revision 0

Table D3-1. Composition of T1 Salt Cakes (3 Sheets).

\begin{tabular}{|c|c|c|c|c|c|c|}
\hline Anaiyte & $\begin{array}{c}\text { Tank } \\
241-\mathrm{T}-108^{\mathrm{a}} \\
(\mu \mathrm{g} / \mathrm{g})\end{array}$ & $\begin{array}{c}\text { Tank } \\
241-\mathrm{T}-109^{\mathrm{b}} \\
(\mu \mathrm{g} / \mathrm{g})\end{array}$ & $\begin{array}{c}\text { Tank } \\
241-\mathrm{TX}-116^{\mathrm{c}} \\
(\mu \mathrm{g} / \mathrm{g})\end{array}$ & $\begin{array}{c}\text { Relative } \\
\text { std dev } \\
\text { of mean } \\
(\%)\end{array}$ & $\begin{array}{c}\text { Predicted } \\
\text { T1 salt } \\
241-\mathrm{TX}-116 \\
\text { layer }(\mu \mathrm{g} / \mathrm{g})\end{array}$ & $\begin{array}{c}\text { HDW } \\
\text { model } \\
\text { T1 SItCk }^{\mathrm{d}} \\
(\mu \mathrm{g} / \mathrm{g})\end{array}$ \\
\hline $\begin{array}{c}\text { Density } \\
(\mathrm{g} / \mathrm{mL})\end{array}$ & $2.35^{\mathrm{g}}$ & $1.55^{\mathrm{h}}$ & $\mathrm{NR}$ & $\mathrm{NA}$ & 1.7 & 1.74 \\
\hline$\% \mathrm{H}_{2} \mathrm{O}$ & $19.5 \%$ & $47.70 \%$ & $7.4 \%$ & NA & $7.4 \%$ & $37.7 \%$ \\
\hline
\end{tabular}

HDW $=$ Hanford Defined Waste

$\mathrm{NR}=$ Not reported

NA $=$ Not applicable

"Baldwin et al. (1996)

b Brown et al. (1996)

- Horton (1997)

d Agnew et al. (1997a), page B-43

' Since these analytes were not expected in this waste, the lower less than was used instead of an average

${ }^{f}$ Predicted T1 salt cake radionuclides are decayed to January 1, 1994. The radionuclides for tanks 241-T-108, 241-T-109, and 241-TX-116 are reported as of the date analyzed; therefore, the average predicted values may not match the reported values

${ }^{3}$ Density reported is actually a particle density measurement, not a bulk density

${ }^{\text {h }}$ The density reported by the 241-T-109 TCR (Brown et al. 1996) was not actually measured, but based on a HDW model Revision 3 estimate (Agnew et al. 1996).

The density for tank $241-\mathrm{T}-108(2.35 \mathrm{~g} / \mathrm{mL})$ is higher than expected, and reflects a laboratory particle density measurement rather than a bulk density determination. Since the $\mathrm{T} 1$ salt cake layer constitutes over 50 percent of the tank 241-TX-116 waste volume, the density of the predicted $\mathrm{T} 1$ salt cake layer in tank 241-TX-116 was arbitrarily set at $1.7 \mathrm{~g} / \mathrm{mL}$ to avoid over-reporting of the waste constituents. The selected value is in good agreement with the HDW model prediction for $\mathrm{T} 1$ salt cake.

The weight percent water reported for the T1 salt cake layer in tank 241-TX-116 is quite low $(7.4 \mathrm{wt} \%)$. The result may reflect either sample dry out or the in-tank effects of the diatomaceous earth addition. No adjustments were made to the weight percent water or the reported analyte concentrations.

\section{D3.4.3 Composition of T2 Salt Cake}

Post-1965 operation of the $242-\mathrm{T}$ Evaporator resulted in $22,672 \mathrm{~kL}(5,990 \mathrm{kgal})$ of salt cake that is contained in 26 underground storage tanks in the S, SX, U, T, TX, and TY Tank Farms (Agnew et al. 1997a). The HDW model refers to this salt cake as T2 SltCk on a global basis or as SMMT2 when calculated by the SMM for an individual tank. The salt 


\section{HNF-SD-WM-ER-705 \\ Revision 0}

cake produced by the 242-T Evaporator from 1965 to 1976 will be referred to as T2 salt cake in this report. Ninety one percent of the T2 salt cake is contained in the TX Tank Farm. All tanks containing T2 salt cake also contain other waste types.

Only 7 tanks containing T2 salt cake other that tank $241-\mathrm{TX}-116$ have been core sampled, 241-S-107, 241-U-102, 241-U-105, 241-U-107, 241-TX-107; 241-TY-102, and 241-TY-103. Only two of these tanks (241-U-102 and 241-U-105) have T2 salt cake layers large enough to differentiate it from other waste types in core sample data at the core segment level.

T2 salt cake was formed in tanks 241-U-102 and 241-U-105 from 1975 through 1976 (Agnew et al. 1997a). Core sampling of tanks 241-U-102 and 241-U-105 was performed in early 1996. Based on the HDW model, segments 4, 5, and 6 for the two cores from tank 241-U-102 and segment 8 of two cores from tank 241-U-105 are expected to be representative of the $\mathrm{T} 2$ salt cake waste type. An independent determination of these levels is not possible due to a lack of solids volume measurements in this time period and the fact a significant composition change between the expected $\mathrm{S} 2$ salt cake and $\mathrm{T} 2$ salt cake layers can not be seen in the core sample data. The recent analytical data should meet all Tri-Party Agreement requirements. Descriptions of the core sampling events and analytical data are available in the respective TCRs (Hu et al. 1997 and Brown and Franklin 1996).

T2 salt cake was deposited in tank 241-TX-116 between 1966 and 1971. The tank 241-TX-116 core sample was taken with the initial prototype of a rotary core sampler between April 1976 and January 1977 (Allen 1977). Sample recoveries were relatively poor. Additionally, analytical methods and quality assurance differed significantly from current practices. However, this sample event provides the composition data directly applicable to tank 241-TX-116.

The analytical data for tank 241-TX-116 are provided in a letter report (Horton 1977). Core segments 1 through 4 are expected to be representative $T 2$ salt cake from the HDW model, and this is confirmed by vertical differences in the core sample results. Diatomaceous earth (92 percent $\mathrm{SiO}_{2}$ ) was added to tank 241-TX-116 in November of 1970 (Buckingham and Metz 1974). The silica from the diatomaceous earth had migrated into the top four core segments (approximately $203 \mathrm{~cm}$ [80 in.]) of the salt cake.

The composition data for tanks 241-U-102, 241-U-105, and 241-TX-116 are summarized in Table D3-2. The analytical results for tanks 241-U-102 and 241-U-105 are mass-weighted averages based on the mass of the partial core segment corresponding to each analytical result. Mass-weighted averages, rather than simple arithmetic averages, were calculated because the core segments were not of equal length and the mass of the partial core segments analyzed varied from approximately $30 \mathrm{~g}$ to $250 \mathrm{~g}$. Similarly, a mass-weighted average was created for the combination of the T2 salt cake in the two U Farm tanks (81.5\% tank $241-\mathrm{U}-102$ and $18.5 \%$ tank $241-\mathrm{U}-105)$. The analytical results for tank 241-TX-116 core segments were simply averaged since the core segments were of equal length. The directly applicable tank 241-TX-116 concentration data will be used for 


\section{Revision 0}

the inventory determination when data are available. The mass-weighted analyte concentration data for the U Tank Farm will be used for analyses that were not performed on the 241-TX-116 samples. The global HDW model composition for T2 salt cake (T2 SltCk) is included in the Table D3-2 for comparison.

Table D3-2. Composition of T2 Salt Cakes. (2 Sheets).

\begin{tabular}{|c|c|c|c|c|c|c|}
\hline Analyte & $\begin{array}{c}241-\mathrm{U}-102 \\
\text { T2 salt cake } \\
\text { wt. avg., } \\
(\mu \mathrm{g} / \mathrm{g})\end{array}$ & $\begin{array}{c}241-\mathrm{U}-105 \\
\text { T2 salt cake } \\
\text { wt. avg.a,c } \\
(\mu \mathrm{g} / \mathrm{g})\end{array}$ & $\begin{array}{c}\text { U Tank } \\
\text { Farm T2 } \\
\text { salt cake } \\
\text { wt. avg." } \\
(\mu \mathrm{g} / \mathrm{g})\end{array}$ & $\begin{array}{c}241-\mathrm{TX}-116 \\
\mathrm{~T} 2 \text { salt cake } \\
\text { mean }^{\star} \\
(\mu \mathrm{g} / \mathrm{g})\end{array}$ & $\begin{array}{c}\text { T2 salt } \\
\text { cake } \\
\text { prediction } \\
(\mu \mathrm{g} / \mathrm{g})\end{array}$ & $\begin{array}{c}\text { HDW T2 } \\
\text { SltCk }^{\mathrm{e}} \\
(\mu \mathrm{g} / \mathrm{g})\end{array}$ \\
\hline $\mathrm{Ag}$ & 11.6 & 19.7 & 13.1 & NR & 13.1 & NR \\
\hline $\mathrm{Al}$ & 18,000 & 12,900 & 17,100 & 33,200 & 33,200 & 17,912 \\
\hline $\mathrm{Bi}$ & $<70.5$ & $<47.2$ & $<66.2$ & NR & $<66.2$ & 221 \\
\hline $\mathrm{Ca}$ & 308 & 253 & 298 & NR & 298 & 1,462 \\
\hline $\mathrm{Cd}$ & $<5.94$ & 12.8 & 7.21 & NR & $<7.21$ & NR \\
\hline $\mathrm{Cl}$ & 5,100 & 5,790 & 5,230 & $\mathrm{NR}$ & 5,230 & 3,328 \\
\hline $\mathrm{CO}_{3}$ & 53,500 & 36,500 & 50,300 & 45,000 & 45,000 & 17,093 \\
\hline $\mathrm{Cr}$ & 2,310 & 2,100 & 2,270 & 330 & 330 & 4260 \\
\hline $\mathrm{F}$ & $<125$ & 1,110 & $<307$ & 2,770 & 2,770 & 931 \\
\hline $\mathrm{Fe}$ & 391 & 2,270 & 737 & 18,800 & 18,800 & 621 \\
\hline $\mathrm{Hg}$ & NR & $\mathrm{NR}$ & NA & NR & NA & 1.13 \\
\hline $\mathrm{K}$ & 1,750 & 1,470 & 1,700 & NR & 1,700 & 1061 \\
\hline $\mathrm{La}$ & $<35.2$ & 29.7 & $<34.2$ & $\mathrm{NR}$ & $<34.2$ & 0.0001 \\
\hline $\mathrm{Mn}$ & 123 & 743 & 237 & NR & 237 & 160 \\
\hline $\mathrm{Na}$ & 262,600 & 220,500 & 254,800 & 142,000 & 142,000 & 192,764 \\
\hline $\mathrm{Ni}$ & 91.5 & 89.5 & 91.1 & $\mathrm{NR}$ & 91.1 & 406 \\
\hline $\mathrm{NO}_{2}$ & 56,700 & 40,100 & 53,600 & 6,830 & 6,830 & 46,096 \\
\hline $\mathrm{NO}_{3}$ & 284,700 & 395,700 & 305,200 & 263,100 & 263,100 & 268,197 \\
\hline $\mathrm{OH}$ & NR & NR & NA & $\mathrm{NA}$ & $\mathrm{NA}$ & 68,079 \\
\hline $\mathrm{Pb}$ & $<119$ & 214 & $<136$ & $\mathrm{NR}$ & $<136$ & 110 \\
\hline $\mathrm{P}$ as $\mathrm{PO}_{4}$ & 5,050 & 14,100 & 6,720 & 7,910 & 7,910 & 7,708 \\
\hline $\mathrm{Si}$ & 152 & 232 & 167 & 155,200 & 155,200 & 1,818 \\
\hline $\mathrm{S}$ as $\mathrm{SO}_{4}$ & 17,900 & 8,350 & 16,200 & 14,000 & 14,000 & 13,823 \\
\hline $\mathrm{Sr}$ & $<7.04$ & $<4.72$ & $<6.61$ & NR & $<6.61$ & 0 \\
\hline TOC & 8,810 & 11,000 & 9,210 & NR & 9,210 & 5,191 \\
\hline
\end{tabular}


Table D3-2. Composition of T2 Salt Cakes. (2 Sheets).

\begin{tabular}{|c|c|c|c|c|c|c|}
\hline Analyte & $\begin{array}{c}241-\mathrm{U}-102 \\
\text { T2 salt cake } \\
\text { wt. avg., } \\
(\mu \mathrm{g} / \mathrm{g})\end{array}$ & $\begin{array}{c}241-\mathrm{U}-105 \\
\text { T2 salt cake } \\
\text { wt. avg. }^{\mathrm{a}, \mathrm{c}} \\
(\mu \mathrm{g} / \mathrm{g})\end{array}$ & $\begin{array}{c}\text { U Tank } \\
\text { Farm T2 } \\
\text { salt cake } \\
\text { wt. avg. } \\
(\mu \mathrm{g} / \mathrm{g})\end{array}$ & $\begin{array}{c}241-\mathrm{TX}-116 \\
\text { T2 salt cake } \\
\text { mean }^{\mathrm{d}} \\
(\mu \mathrm{g} / \mathrm{g})\end{array}$ & $\begin{array}{c}\text { T2 salt } \\
\text { cake } \\
\text { prediction } \\
(\mu \mathrm{g} / \mathrm{g})\end{array}$ & $\begin{array}{c}\text { HDW T2 } \\
\text { SltCk } \\
(\mu \mathrm{g} / \mathrm{g})\end{array}$ \\
\hline $\mathrm{U}$ & $<353$ & 545 & $<388$ & NR & $<388$ & 2,174 \\
\hline $\mathrm{Zr}$ & 10.8 & 45.4 & 17.2 & NR & 17.2 & 14.7 \\
\hline $\begin{array}{l}\text { Radio- } \\
\text { nuclide }^{f}\end{array}$ & $\begin{array}{c}241-\mathrm{U}-102 \\
\mathrm{~T} 2 \text { salt cake } \\
\text { avg., } \\
(\mu \mathrm{Ci} / \mathrm{g})\end{array}$ & $\begin{array}{c}241-\mathrm{U}-105 \\
\text { T2 salt cake } \\
\text { avg., } \\
(\mu \mathrm{Ci} / \mathrm{g})\end{array}$ & $\begin{array}{c}\text { U Tank } \\
\text { Farm T2 } \\
\text { salt cake } \\
\text { avg. }{ }^{\mathrm{a}} \\
(\mu \mathrm{Ci} / \mathrm{g})\end{array}$ & $\begin{array}{c}241-\mathrm{TX}-116 \\
\text { T2 salt cake } \\
\text { mean }^{d} \\
(\mu \mathrm{Ci} / \mathrm{g})\end{array}$ & $\begin{array}{c}\text { T2 salt } \\
\text { cake } \\
\text { prediction } \\
(\mu \mathrm{Ci} / \mathrm{g})\end{array}$ & $\begin{array}{c}\text { HDW T2 } \\
\text { SltCk } \\
(\mu \mathrm{Ci} / \mathrm{g})\end{array}$ \\
\hline${ }^{241} \mathrm{Am}$ & $<37.0$ & $<0.95$ & $<30.3$ & NR & $<30.3$ & 0.0285 \\
\hline${ }^{60} \mathrm{Co}$ & $<0.155$ & 0.086 & $<0.142$ & NR & $<0.142$ & 0.027 \\
\hline${ }^{134} \mathrm{Cs}$ & NR & NR & $\mathrm{NA}$ & $9.23 \mathrm{E}-04$ & $9.23 \mathrm{E}-04$ & 0.0016 \\
\hline${ }^{137} \mathrm{Cs}$ & 197 & 145 & 188 & 31.1 & 31.1 & 163 \\
\hline${ }^{154} \mathrm{Eu}$ & $<0.475$ & 0.61 & $<0.499$ & NR & $<0.499$ & 0.431 \\
\hline${ }^{155} \mathrm{Eu}$ & $<1.10$ & 0.82 & $<1.05$ & NR & $<1.05$ & 0.185 \\
\hline $\begin{array}{l}\text { Density } \\
(\mathrm{g} / \mathrm{mL})\end{array}$ & 1.66 & 1.73 & $1.70^{g}$ & NR & 1.70 & 1.63 \\
\hline
\end{tabular}

HDW $=$ Hanford Defined Waste

NR $=$ Not reported

${ }^{a}$ Weighted average based on the mass of each partial core segment analyzed

${ }^{\mathrm{b}} \mathrm{Hu}$ et al. (1997)

c Brown and Franklin (1996)

.${ }^{d}$ Horton (1977)

'Agnew et al. (1997a), page B-43

${ }^{\mathrm{f}}$ Radionuclides decayed to January 1, 1994

${ }^{8}$ A sample average is used for density.

The predicted T2 salt cake composition for tank 241-TX-116 should be viewed only as an approximation. The iron and silicon concentration data for tank 241-TX-116 T2 salt are unreasonably high. The T2 salt cake projected by the HDW model in tanks 241-U-102 and 241-U-105 could be erroneous if the transfers were TX Tank Farm supernatants (i.e., saturated salt solutions that had already cooled and would not form additional salt cake) and formed rather than actual evaporator bottoms. 


\section{Revision 0}

\section{D3.4.3 Diatomaceous Earth Addition}

Approximately 95.3 MT of diatomaceous earth was added to tank 241-TX-116 in November 1970 to demonstrate absorption of free liquids in waste tanks (Buckingham and Metz 1974). Diatomaceous earth is the siliceous skeletal remains of single-cell algae. The composition of the diatomaceous earth added to tank 241-TX-116 is provided in Table D4-3.

Table D3-3. Diatomaceous Earth Addition to 241-TX-116.

\begin{tabular}{|c|c|c|c|}
\hline Chemical compound & Weight percent $^{\mathrm{a}}$ & Element & Element added (kg) \\
\hline $\mathrm{SiO}_{2}$ & 92.3 & $\mathrm{Si}$ & 41,100 \\
\hline $\mathrm{Al}_{2} \mathrm{O}_{3}$ & 1.1 & $\mathrm{Al}$ & 554 \\
\hline $\mathrm{Fe}_{2} \mathrm{O}_{3}$ & 2.0 & $\mathrm{Fe}$ & 1,330 \\
\hline $\mathrm{CaO}$ & 0.9 & $\mathrm{Ca}$ & 613 \\
\hline $\mathrm{MgO}$ & 0.4 & $\mathrm{Mg}$ & 230 \\
\hline Loss on ignition & 3.1 & Unknown & 2,950 \\
\hline
\end{tabular}

${ }^{a}$ Buckingham and Metz (1974).

\section{D3.5 PREDICTED INVENTORY FOR TANK 241-TX-116}

The chemical and radionuclide inventory of tank $241-\mathrm{TX}-116$ can be estimated from the T1 salt cake and T2 salt cake/diatomaceous earth layer volumes $(1,223 \mathrm{~kL}$ [323 kgal], and $1,166 \mathrm{~kL}$ [308 kgal], respectively), densities $(1.7 \mathrm{~g} / \mathrm{mL})$, and the chemical $/$ radionuclide concentrations measured for the 1976 core sample, augmented with data from other $\mathrm{T} 1$ and T2 salt cake tanks. The resulting inventories are provided in Table D3-4. The inventories estimated by the HDW model (Agnew et al. 1997a) are included in the table for comparison. 


\section{Revision 0}

Table D3-4. Estimated Chemical and Radionuclide Inventory for Tank 241-TX-116. (2 sheets)

\begin{tabular}{|c|c|c|c|c|}
\hline Analyte & $\begin{array}{c}\text { T1 salt cake } \\
\text { layer } \\
\text { inventory }(\mathrm{kg})\end{array}$ & $\begin{array}{c}\text { T2 salt cake/DE } \\
\text { layer } \\
\text { inventory } \\
\text { ing }\end{array}$ & $\begin{array}{c}\text { Predicted } \\
241-\mathrm{TX}-116 \\
\text { inventory }(\mathrm{kg})\end{array}$ & $\begin{array}{l}\text { HDW model } \\
\text { inventory }(\mathrm{kg})\end{array}$ \\
\hline $\mathrm{Ag}$ & $<27.6$ & 26.0 & $<53.6$ & NR \\
\hline Al & 3,750 & 65,800 & 69,400 & 24,300 \\
\hline $\mathrm{Bi}$ & 805 & $<131$ & $<936$ & 4,140 \\
\hline $\mathrm{Ca}$ & 521 & 590 & 1,110 & 6,200 \\
\hline $\mathrm{Cd}$ & $<10.4$ & $<14.3$ & $<24.7$ & $\mathrm{NR}$ \\
\hline $\mathrm{Cl}$ & 709 & 10,400 & 11,100 & 7,480 \\
\hline $\mathrm{CO}_{3}$ & 70,400 & 89,200 & 159,600 & 28,800 \\
\hline $\mathrm{Cr}$ & 312 & 654 & 966 & 3,630 \\
\hline$F$ & 6,420 & 5,480 & 11,900 & 3,320 \\
\hline $\mathrm{Fe}$ & 33,200 & 37,200 & 70,400 & 10,200 \\
\hline $\mathrm{Hg}$ & NR & $\mathrm{NR}$ & $\mathrm{NA}$ & 3.04 \\
\hline $\mathrm{K}$ & $<497$ & 3,370 & $<3,870$ & 1,960 \\
\hline $\mathrm{La}$ & $<82.7$ & $<67.8$ & $<151$ & 9.97 E-05 \\
\hline $\mathrm{Mn}$ & 1,260 & 470 & 1,730 & 99.2 \\
\hline $\mathrm{Na}$ & 514,000 & 281,400 & 795,400 & 628,000 \\
\hline $\mathrm{Ni}$ & $<37$ & 181 & $<218$ & 1,090 \\
\hline $\mathrm{NO}_{2}$ & 416 & 13,500 & 14,000 & 69,800 \\
\hline $\mathrm{NO}_{3}$ & $1.196 \mathrm{E}+06$ & 521,500 & $1.717 \mathrm{E}+06$ & 891,000 \\
\hline $\mathrm{Pb}$ & 869 & $<270$ & $<1,140$ & 181 \\
\hline $\mathrm{PO}_{4}$ & 29,000 & 15,700 & 44,700 & 157,000 \\
\hline $\mathrm{Si}$ & 15,100 & 307,600 & 322,700 & 42,800 \\
\hline $\mathrm{SO}_{4}$ & 71,700 & 27,700 & 99,400 & 27,700 \\
\hline $\mathrm{Sr}$ & $<32.8$ & $<13.1$ & $<45.9$ & 0 \\
\hline TOC & NR & NR & NR & 2,870 \\
\hline $\mathrm{U}$ & 5.80 & $<769$ & $<775$ & 22,300 \\
\hline $\mathrm{Zr}$ & 24.0 & 34.1 & 58.1 & 67.8 \\
\hline
\end{tabular}




\section{Revision 0}

Table D3-4. Estimated Chemical and Radionuclide Inventory for

Tank 241-TX-116. (2 sheets)

\begin{tabular}{|c|c|c|c|c|}
\hline Radionuclide $^{\mathrm{c}}$ & $\begin{array}{c}\text { T1 salt cake } \\
\text { layer (Ci) }\end{array}$ & $\begin{array}{c}\text { T2 salt cake/DE } \\
\text { layer (Ci) }\end{array}$ & $\begin{array}{c}\text { Predicted } \\
241-\mathrm{TX}-116 \\
\text { inventory (Ci) }\end{array}$ & $\begin{array}{c}\text { HDW model } \\
\text { inventory (Ci) }\end{array}$ \\
\hline${ }^{241} \mathrm{Am}$ & $<256$ & $<60,100$ & $<60,400$ & 27.7 \\
\hline${ }^{60} \mathrm{Co}$ & $<33.7$ & $<281$ & $<315$ & 18.7 \\
\hline${ }^{134} \mathrm{Cs}$ & 16.2 & 1.83 & 18.1 & 1.31 \\
\hline${ }^{137} \mathrm{Cs}$ & 6,650 & 61,600 & 68,300 & 247,000 \\
\hline${ }^{154} \mathrm{Eu}$ & $<107$ & $<989$ & $<1,100$ & 294 \\
\hline${ }^{155} \mathrm{Eu}$ & $<105$ & $<2,070$ & $<2,180$ & 117 \\
\hline
\end{tabular}

$\mathrm{DE}=$ diatomaceous earth

HDW = Hanford Defined Waste, Agnew et al. (1997a)

$\mathrm{NA}=$ Not applicable

$\mathrm{NR}=$ Not reported

${ }^{\mathrm{a}}$ Based on the T1 salt cake prediction in Table D3-1.

${ }^{b}$ Based on the T2 salt cake prediction in Table D3-2, includes diatomaceous earth.

c Radionuclides decayed to January 1, 1994.

\section{D3.6 COMPARISON OF TANK 241-TX-116 INVENTORY ESTIMATES}

The lack of recent core sample from tank $241-T X-116$ adds considerable uncertainty to estimation of chemical and radionuclide inventories for the tank. The use of waste composition data from the 1976 core sample from tank 241-TX-116 and data for tanks 241-T-108, 241-T-109, 241-TX-116, 241-U-102, and 241-U-105 to represent the wastes in tank 241-TX-116 is a reasonable approach in the absence of recent core sample. However, several problems were noted concerning the analytical data for the 1976 core sample of 241-TX-116 including: (1) an excessively high iron concentration for a salt cake waste, (2) the T2 salt cake layer silicon inventory is 7.5 times the amount estimated from the diatomaceous earth additions, and (3) the T1 salt cake moisture content $(7.4 \mathrm{wt} \%)$ is extremely low considering the moisture content of the T2 salt cake layer $(28 \mathrm{wt} \%)$. The estimate should be regarded only an approximation.

The tank 241-TX-116 inventories predicted by the HDW model and the estimate based on the 1976 241-TX-116 core sample and waste analyses in other tanks are markedly different. Of the major chemical species, only the sodium inventories are in reasonable agreement.

The HDW model prediction of the tank 241-TX-116 chemical inventories appears to be biased low because: (1) the calculated waste density of $1.50 \mathrm{~g} / \mathrm{mL}$ is lower than expected for 


\section{Revision 0}

a salt cake waste, (2) the HDW model calculated the total waste volume from a flawed solids level measurement, and (3) the HDW model fails to account for the liquid waste absorbed by the diatomaceous earth (see discussion of diatomaceous earth additions later in this section).

Aluminum. The estimated aluminum inventory is 2.9 times higher than that predicted by the HDW model. This difference is attributable in part to the low salt cake densities calculated by the HDW model (approximately $1.5 \mathrm{~g} / \mathrm{cc}$ ), as compared to the $1.7 \mathrm{~g} / \mathrm{mL}$ estimated from analytical data for $\mathrm{T} 2$ salt cakes, and the reduced total waste volume assumed by the HDW model. Additionally, the tank 241-TX-116 analytical results show a much higher aluminum concentration than predicted by the HDW model.

Carbonate and Hydroxide. The estimated tank 241-TX-116 carbonate inventory is 5.5 times the HDW model inventory. The hydroxide ion in Hanford Site waste tanks is converted to carbonate by the absorption of carbon dioxide from the ambient air. One mole of absorbed carbon dioxide will react with two moles of hydroxide ion to form one mole of carbonate ion. The rate is difficult to model at best, and is accelerated by the use of airlift circulators such as those installed in numerous several Hanford Site tanks. Conversion of $74,100 \mathrm{~kg}$ of hydroxide to carbonate would account for the difference. The HDW model does not adequately account for the absorption of carbon dioxide from the atmosphere.

Fluorides. The estimated fluoride inventory is 3.6 times that predicted by the HDW model. This is possibly the result of the HDW model assumptions that sodium fluoride is. the only chemical compound containing fluoride and that it does not precipitate. The formation of insoluble fluoride compounds (such as sodium fluorophosphate) may be causing some fluoride to precipitate and remain in the tank.

Iron. The estimated iron inventory is skewed by the high iron concentrations (1.6 and $1.88 \mathrm{wt} \%)$ reported for tank $241-\mathrm{TX}-116 \mathrm{~T} 1$ and $\mathrm{T} 2$ salt cakes. A later analysis of the tank 241-TX-116 salt cake (Schulz 1980) indicated very little insoluble material. The high iron concentration is not likely for a salt cake since iron is insoluble in alkaline solutions and significant iron concentration would not be expected in the evaporator feed solutions. Therefore, the HDW model iron inventory will be used for the best-basis.

Nitrate. The estimated nitrate inventory is 1.9 times that predicted by the HDW model. Much of the HDW model salt cake inventory is predicted by the SMM, and it is, therefore, difficult to determine the specific causes of this discrepancy. Part of the discrepancy results from the HDW prediction of a high phosphate concentration in the T1 salt cake layer, which is not supported by the analyses of the 1976 core sample. The global HDW model T2 salt cake concentration for nitrate is in good agreement with the 1976 core sample results (Table D3-2), although the HDW model nitrate concentration for T1 salt cake is substantially lower than the core sample results (see Table D3-1). The difference may primarily be the result of a highly variable composition for T1 salt cakes.

Phosphate. The HDW model phosphate inventory is 3.5 times that calculated from the 1976 core sample. The HDW model predicts a phosphate concentration of about 7 wt \% for 


\section{Revision 0}

the T1 salt cake layer; as compared to about $1.4 \mathrm{wt} \%$ for the 1976 core sample. It is conceivable that higher phosphate levels might be present in the bottom $307 \mathrm{~kL}(81,000 \mathrm{gal})$ of waste that were not sampled. However, the phosphate concentrations in T1 salt cake appear to be highly variable (see Section D3.4.1). The phosphate inventory calculated from the 1976 core sample analyses will be used for the best-basis.

Sodium. The predicted HDW sodium inventory is about 79 percent that predicted from analytical data for other T1 and T2 salt cake tanks. The lower HDW model waste density and total waste volume would explain most of the difference. Increasing the T2 salt cake layer by $257 \mathrm{~kL}(68 \mathrm{kgal})$ and increasing the waste specific gravity to $1.7 \mathrm{~g} / \mathrm{mL}$ would result in a sodium inventory of $782,000 \mathrm{~kg}$, which is within 2 percent of the inventory estimated form the 1976 core sample analytical results.

Uranium. The uranium concentrations measured for the 1976 core sample of tank 241-TX-116 is far below that measured in other T1 and T2 salt cakes tanks (see Tables D3-1 and D3-2). The uranium concentrations predicted by the HDW model for tank 241-TX-116 are far higher than any measured values. As a consequence, the best-basis uranium inventory for tank 241-TX-116 will be based on the average concentrations measured in other $\mathrm{T} 1$ and $\mathrm{T} 2$ salt cake tanks $(<2,460 \mathrm{~kg})$.

Total Hydroxide. Once the best-basis inventories were determined, the hydroxide inventory was calculated by performing a charge balance with the valences of the other analytes. In some cases, this approach requires that other analyte (e.g., sodium or nitrate) inventories be adjusted to achieve the charge balance. During such adjustments, the number of significant figures is not increased. The charge balance approach is consistent with that used by Agnew et al. (1997a). The revised total hydroxide inventory based on the best-basis inventory is $40,300 \mathrm{~kg}$, which is about 50 percent of the HDW model estimate. The difference results from the higher concentrations of nitrate, carbonate and sulfate reported for the 1976 core sample.

Diatomaceous Earth. The HDW model does not account for the liquid waste absorbed on the diatomaceous earth added to tank 241-TX-116. An acceptable alternative would be to allow the Tank Layer Model (TLM) to fill the void space in the diatomaceous earth with supernatant. However, the void fraction for the predicted diatomaceous earth sludge was set to zero, which causes the exclusion of supernatant. The density of the diatomaceous earth layer consequently remained at $0.39 \mathrm{~g} / \mathrm{mL}$. The HDW model treatment of diatomaceous earth additions to tank wastes needs improvement.

Cesium-137 and Strontium-90. The heat load for tank 241-TX-116 was not estimated (Kummerer 1995) because waste and vapor space temperature data were not available. The lack of a heat load estimate makes evaluation of validity of ${ }^{137} \mathrm{Cs}$ and ${ }^{90} \mathrm{Sr}$ inventories difficult. The HDW ${ }^{137} \mathrm{Cs}$ inventory is 3.6 times that predicted from 1976 core sample analytical data. Most of the ${ }^{137} \mathrm{Cs}$ is located in the T2 salt cake layer. The ${ }^{137} \mathrm{Cs}$ concentration predicted by the HDW model for the tank 241-TX-116 T2 salt cake layer is in good agreement with the concentrations measured in tanks $241-\mathrm{U}-102$ or $241-\mathrm{U}-105$. The 


\section{HNF-SD-WM-ER-705}

\section{Revision 0}

HDW model inventory will be used as the best-basis. The HDW model inventory for ${ }^{90} \mathrm{Sr}$ will also be used for the best-basis due to the lack of ${ }^{90} \mathrm{Sr}$ analytical data. Tank 241-TX-116 did not store complexed wastes (designated as EVT in the waste transactions, Agnew et al. 1997b) containing relatively high ${ }^{90} \mathrm{Sr}$ concentrations during 1974 to 1976 , so the $66,000 \mathrm{Ci}$ ${ }^{90} \mathrm{Sr} \mathrm{HDW}$ model inventory is not unreasonably low. 


\section{D4.0 DEFINE THE BEST-BASIS AND ESTABLISH COMPONENT INVENTORIES}

Information about chemical, radiological, and/or physical properties is used to perform safety analyses, engineering evaluations, and risk assessment associated with waste management activities, as well as regulatory issues. These activities include overseeing tank farm operations and identifying, monitoring, and resolving safety issues associated with these operations and with the tank wastes. Disposal activities involve designing equipment, processes and facilities for retrieving wastes and processing them into a form that is suitable for long-term storage.

Chemical and radiological inventory information are generally derived using three approaches: (1) component inventories are estimated using the results of sample analyses, (2) component inventories are predicted using the HDW model based on process knowledge and historical information, or (3) a tank-specific process estimate is made based on process flowsheets, reactor fuel data, essential material usage, and other operating data.

An effort is underway to provide waste inventory estimates that will serve as the standard characterization for the various waste management activities (Hodgson and LeClair 1996). As part of this effort, an evaluation of available information for tank 241-TX-116 was performed including the following:

- A core sample taken from tank 241-TX-116 in 1976 (Horton 1977).

- Waste transactions and operating data to confirm that only 242-T Evaporator salt cakes and diatomaceous earth were expected in this tank.

- Composition data from two waste tanks (241-T-108 and 241-T-109 [Baldwin et al. 1996 and Brown et al. 1996]) that are expected to have a similar T1 salt cake compositions, and two waste tanks (241-U-102 and 241-U-105 [Hu et al. 1997 and Brown and Franklin 1996]) that are expected to have similar T2 salt cake compositions.

- An inventory estimate generated by the HDW model (Agnew et al. 1997a)

Based on this evaluation, a best-basis inventory was developed. No recent analytical data are available for the salt cake remaining in tank 241 -TX-116 because no core samples have been taken since 1976 . The estimated inventory was, therefore, based on the analytical data reported for the 1976 core sample, the composition of T1 salt cakes in tanks 241-T-108 and 241-T-109, and the composition of T2 salt cakes in tanks 241-U-102 and 241-U-105. The HDW model inventories were used when no other data were available or when analytical data were suspect.

The waste in tank 241-TX-116 consists of $1,223 \mathrm{~kL}$ ( $323 \mathrm{kgal}$ ) of T1 salt cake, $908 \mathrm{~kL}$ (240 kgal) of T2 salt cake, and $257 \mathrm{~kL}$ ( $68 \mathrm{kgal}$ ) of diatomaceous earth. The diatomaceous 


\section{Revision 0}

earth is dispersed in the salt cake (primarily the T2 salt cake layer), and is no longer present at a separate waste layer. The best-basis inventory for tank 241-TX-116 is presented in Tables D4-1 and D4-2. The inventory values reported in Tables D4-1 and D4-2 are subject to change. Refer to the Tank Characterization Database (TCD) for the most current inventory values.

Best-basis tank inventory values are derived for 46 key radionuclides (as defined in Section 3.1 of Kupfer et al. 1997), all decayed to a common report date of January 1, 1994. Often, waste sample analyses have only reported ${ }^{90} \mathrm{Sr},{ }^{137} \mathrm{Cs},{ }^{239 / 240} \mathrm{Pu}$, and total uranium (or total beta and total alpha), while other key radionuclides such as ${ }^{60} \mathrm{Co},{ }^{99} \mathrm{Tc},{ }^{129} \mathrm{I},{ }^{154} \mathrm{Eu},{ }^{155} \mathrm{Eu}$, and ${ }^{241} \mathrm{Am}$, etc., have been infrequently reported. For this reason it has been necessary to derive most of the 46 key radionuclides by computer models. These models estimate radionuclide activity in batches of reactor fuel, account for the split of radionuclides to various separations plant waste streams, and track their movement with tank waste transactions. (These computer models are described in Kupfer et al. 1997, Section 6.1 and in Watrous and Wootan 1997.) Model generated values for radionuclides in any of 177 tanks are reported in the HDW Rev. 4 model results (Agnew et al. 1997a). The best-basis value for any one analyte may be either a model result or a sample or engineering assessment-based result if available. (No attempt has been made to ratio or normalize model results for all 46 radionuclides when values for measured radionuclides disagree with the model.) For a discussion of typical error between model derived values and sample derived values, see Kupfer et al. 1997, Section 6.1.10. 
HNF-SD-WM-ER-705

Revision 0

Table D4-1. Best-Basis Inventory Estimates for Nonradioactive Components in Tank 241-TX-116 (Effective May 31, 1997). (2 Sheets)

\begin{tabular}{|c|c|c|c|}
\hline Analyte & $\begin{array}{c}\text { Total inventory } \\
(\mathrm{kg})\end{array}$ & $\begin{array}{c}\text { Basis } \\
(\mathrm{S}, \mathrm{M}, \mathrm{E}, \text { or } \mathrm{C})^{1}\end{array}$ & Comment \\
\hline $\mathrm{Al}$ & 69,400 & $\mathrm{~S}$ & \\
\hline $\mathrm{Bi}$ & $<936$ & $E$ & \\
\hline $\mathrm{Ca}$ & 1,110 & $\mathrm{E}$ & \\
\hline $\mathrm{Cl}$ & 11,100 & $\mathrm{E}$ & \\
\hline $\mathrm{TIC}$ as $\mathrm{CO}_{3}$ & 160,000 & $S$ & \\
\hline $\mathrm{Cr}$ & 966 & $S$ & \\
\hline$F$ & 11,900 & $S$ & \\
\hline $\mathrm{Fe}$ & 10,200 & $\mathrm{M}$ & \\
\hline $\mathrm{Hg}$ & 3.0 & $\mathrm{M}$ & \\
\hline $\mathrm{K}$ & $<3,870$ & $\mathrm{E}$ & $\begin{array}{l}\text { The T2 salt cake layer potassium } \\
\text { inventory is } 3,370 \mathrm{~kg} \text {. }\end{array}$ \\
\hline $\mathrm{La}$ & $1.0 \mathrm{E}-04$ & $\mathrm{M}$ & \\
\hline $\mathrm{Mn}$ & 1,730 & $E$ & \\
\hline $\mathrm{Na}$ & 795,400 & $S$ & \\
\hline $\mathrm{Ni}$ & $<218$ & $\mathrm{E}$ & \\
\hline $\mathrm{NO}_{2}$ & 14,000 & $S$ & \\
\hline $\mathrm{NO}_{3}$ & $1.72 \mathrm{E}+06$ & $S$ & $\begin{array}{l}\text { Concentration varies significantly } \\
\text { between } \mathrm{T} 1 \text { salt cakes. }\end{array}$ \\
\hline $\mathrm{OH}_{\text {TOTAL }}$ & 40,300 & $\mathrm{C}$ & Estimated by ion charge balance. \\
\hline $\mathrm{Pb}$ & $<1,140$ & $\mathrm{E}$ & \\
\hline $\mathrm{P}$ as $\mathrm{PO}_{4}$ & 44,700 & $S$ & $\begin{array}{l}\text { Concentration varies significantly } \\
\text { between } \mathrm{T} 1 \text { salt cakes. }\end{array}$ \\
\hline $\mathrm{Si}$ & 42,800 & $\mathrm{M}$ & $\begin{array}{l}\text { Si added with diatomaceous earth was } \\
41,100 \mathrm{~kg} \text {. }\end{array}$ \\
\hline $\mathrm{S}$ as $\mathrm{SO}_{4}$ & 99,400 & $S$ & \\
\hline $\mathrm{Sr}$ & $<46$ & $\mathrm{E}$ & \\
\hline TOC & 2,870 & $M$ & \\
\hline $\mathrm{U}_{\text {TOTAL }}$ & $<2,460$ & $\mathrm{E}$ & $\begin{array}{l}\text { Estimated from } \mathrm{T} 1 \text { salt cake } \\
\text { concentrations in other tanks and the } \mathrm{U} \\
\text { Tank Farm } \mathrm{T} 2 \text { salt cake wt. avg. }\end{array}$ \\
\hline
\end{tabular}


HNF-SD-WM-ER-705

Revision 0

Table D4-1. Best-Basis Inventory Estimates for Nonradioactive Components in Tank 241-TX-116 (Effective May 31, 1997). (2 Sheets)

\begin{tabular}{|c|c|c|c|}
\hline Analyte & $\begin{array}{c}\text { Total inventory } \\
(\mathrm{kg})\end{array}$ & $\begin{array}{c}\text { Basis } \\
(\mathrm{S}, \mathrm{M}, \mathrm{E}, \text { or } \mathrm{C})^{1}\end{array}$ & Comment \\
\hline $\mathrm{Zr}$ & 58 & $\mathrm{E}$ & \\
\hline
\end{tabular}

${ }^{1} \mathrm{~S}=$ Sample-based

$M=$ Hanford Defined Waste model-based, Agnew et al. (1996)

$\mathrm{E}=$ Engineering assessment-based

$\mathrm{C}=$ Calculated by charge balance; includes oxides as hydroxides, not including $\mathrm{CO}_{3}$, $\mathrm{NO}_{2}, \mathrm{NO}_{3}, \mathrm{PO}_{4}, \mathrm{SO}_{4}$, and $\mathrm{SiO}_{3}$. 


\section{Revision 0}

Table D4-2. Best-Basis Inventory Estimates for Radioactive Components in Tank 241-TX-116, Decayed to January 1, 1994 (Effective May 31, 1997). (2 Sheets)

\begin{tabular}{|c|c|c|l|}
\hline Analyte & $\begin{array}{c}\text { Total inventory } \\
(\mathrm{Ci})\end{array}$ & $\begin{array}{c}\text { Basis } \\
(\mathrm{S}, \mathrm{M}, \text { or } \mathrm{E})\end{array}$ & \\
\hline${ }^{3} \mathrm{H}$ & 119 & $\mathrm{M}$ & \\
\hline${ }^{14} \mathrm{C}$ & 17.5 & $\mathrm{M}$ & \\
\hline${ }^{59} \mathrm{Ni}$ & 2.43 & $\mathrm{M}$ & \\
\hline${ }^{60} \mathrm{Co}$ & 18.7 & $\mathrm{M}$ & \\
\hline${ }^{63} \mathrm{Ni}$ & 229 & $\mathrm{M}$ & \\
\hline${ }^{79} \mathrm{Se}$ & 1.79 & $\mathrm{M}$ & \\
\hline${ }^{90} \mathrm{Sr}$ & 66,000 & $\mathrm{M}$ & \\
\hline${ }^{90} \mathrm{Y}$ & 66,000 & $\mathrm{M}$ & \\
\hline${ }^{93} \mathrm{Zr}$ & 8.80 & $\mathrm{M}$ & \\
\hline${ }^{93 \mathrm{~m}} \mathrm{Nb}$ & 6.42 & $\mathrm{M}$ & \\
\hline${ }^{99} \mathrm{Tc}$ & 125 & $\mathrm{M}$ & \\
\hline${ }^{106} \mathrm{Ru}$ & 0.00303 & $\mathrm{M}$ & \\
\hline${ }^{113 \mathrm{~m}} \mathrm{Cd}$ & 44.6 & $\mathrm{M}$ & \\
\hline${ }^{125} \mathrm{Sb}$ & 78.5 & $\mathrm{M}$ & \\
\hline${ }^{126} \mathrm{Sn}$ & 2.70 & $\mathrm{M}$ & \\
\hline${ }^{129} \mathrm{I}$ & 0.241 & $\mathrm{M}$ & \\
\hline${ }^{134} \mathrm{Cs}$ & 1.31 & $\mathrm{M}$ & \\
\hline${ }^{137} \mathrm{Cs}$ & 247,000 & $\mathrm{M}$ & \\
\hline${ }^{137 \mathrm{~m}} \mathrm{Ba}$ & 233,000 & $\mathrm{M}$ & \\
\hline${ }^{151} \mathrm{Sm}$ & 6,320 & $\mathrm{M}$ & \\
\hline${ }^{152} \mathrm{Eu}$ & 1.93 & $\mathrm{M}$ & \\
\hline${ }^{154} \mathrm{Eu}$ & 294 & $\mathrm{M}$ & \\
\hline${ }^{155} \mathrm{Eu}$ & 117 & $\mathrm{M}$ & \\
\hline${ }^{226} \mathrm{Ra}$ & $1.11 \mathrm{E}-04$ & $\mathrm{M}$ & \\
\hline${ }^{227} \mathrm{Ac}$ & $7.06 \mathrm{E}-04$ & $\mathrm{M}$ & \\
\hline${ }^{228} \mathrm{Ra}$ & 0.167 & $\mathrm{M}$ & \\
\hline${ }^{229} \mathrm{Th}$ & 0.00388 & $\mathrm{M}$ & \\
\hline${ }^{231} \mathrm{~Pa}$ & 0.00281 & $\mathrm{M}$ & \\
\hline${ }^{232} \mathrm{Th}$ & 0.0103 & $\mathrm{M}$ & \\
\hline${ }^{232} \mathrm{U}$ & 0.829 & $\mathrm{M}$ & \\
\hline & 3.17 & $\mathrm{M}$ & \\
\hline & & & \\
\hline
\end{tabular}


HNF-SD-WM-ER-705

\section{Revision 0}

Table D4-2. Best-Basis Inventory Estimates for Radioactive Components in Tank 241-TX-116, Decayed to January 1, 1994 (Effective May 31, 1997). (2 Sheets)

\begin{tabular}{|c|c|c|l|}
\hline Analyte & $\begin{array}{c}\text { Total inventory } \\
(\mathrm{Ci})\end{array}$ & $\begin{array}{c}\text { Basis } \\
(\mathrm{S}, \mathrm{M}, \text { or } \mathrm{E})^{\mathrm{1}}\end{array}$ & Comment \\
\hline${ }^{234} \mathrm{U}$ & 7.40 & $\mathrm{M}$ & \\
\hline${ }^{235} \mathrm{U}$ & 0.326 & $\mathrm{M}$ & \\
\hline${ }^{236} \mathrm{U}$ & 0.0834 & $\mathrm{M}$ & \\
\hline${ }^{237} \mathrm{~Np}$ & 0.458 & $\mathrm{M}$ & \\
\hline${ }^{238} \mathrm{Pu}$ & 1.12 & $\mathrm{M}$ & \\
\hline${ }^{238} \mathrm{U}$ & 7.69 & $\mathrm{M}$ & \\
\hline${ }^{239} \mathrm{Pu}$ & 98.9 & $\mathrm{M}$ & \\
\hline${ }^{240} \mathrm{Pu}$ & 9.96 & $\mathrm{M}$ & \\
\hline${ }^{241} \mathrm{Am}$ & 27.7 & $\mathrm{M}$ & \\
\hline${ }^{241} \mathrm{Pu}$ & 60.6 & $\mathrm{M}$ & \\
\hline${ }^{242} \mathrm{Cm}$ & 0.0704 & $\mathrm{M}$ & \\
\hline${ }^{242} \mathrm{Pu}$ & $3.08 \mathrm{E}-04$ & $\mathrm{M}$ & \\
\hline${ }^{243} \mathrm{Am}$ & $9.41 \mathrm{E}-04$ & $\mathrm{M}$ & \\
\hline${ }^{243} \mathrm{Cm}$ & 0.00635 & $\mathrm{M}$ & \\
\hline${ }^{244} \mathrm{Cm}$ & 0.0643 & $\mathrm{M}$ & \\
\hline
\end{tabular}

${ }^{1} \mathrm{~S}=$ Sample-based

M = Hanford Defined Waste model-based, Agnew et al. (1997a)

$\mathrm{E}=$ Engineering assessment-based. 
HNF-SD-WM-ER-705

Revision 0

\section{D5.0 APPENDIX D REFERENCES}

Agnew, S. F., J. Boyer, R. A. Corbin, T. B. Duran, J. R. FitzPatrick, K. A. Jurgensen, T. P. Ortiz, and B. L. Young, 1996, Hanford Tank Chemical and Radionuclide Inventories: HDW Model Rev. 3, LA-UR-96-858, Los Alamos National Laboratory, Los Alamos, New Mexico.

Agnew, S. F., J. Boyer, R. A. Corbin, T. B. Duran, J. R. FitzPatrick, K. A. Jurgensen, T. P. Ortiz, and B. L. Young, 1997a, Hanford Tank Chemical and Radionuclide Inventories: HDW Model Rev. 4, LA-UR-96-3860, Los Alamos National Laboratory, Los Alamos, New Mexico.

Agnew, S. F., R. A. Corbin, T. B. Duran, K. A. Jurgensen, T. P. Ortiz, and B. L. Young, 1997b, Waste Status and Transaction Record Summary (WSTRS Rev. 4), LA-UR-97-311, Rev. 0, Los Alamos National Laboratory, Los Alamos, New Mexico.

Allen, G. K., 1977, Salt Cake and Sludge Characterization Program 241-TX-116 Hot Test and Subsequent Cold Test Results, RHO-CD-3, Rockwell Hanford Operations, Richland, Washington.

Anderson, J. D., 1990, A History of the 200 Area Tank Farms, WHC-MR-0132, Westinghouse Hanford Company, Richland, Washington.

Baldwin, J. H., J. L. Stroup, L. C. Amato; and B. J. Morris, 1996, Tank Characterization Report for Single-Shell Tank 241-T-108, WHC-SD-WM-ER-554, Rev. OA, Westinghouse Hanford Company, Richland, Washington.

Brevick, C. H., J. L. Stroup, and J. W. Funk, 1997, Historical Tank Content Estimate for the Northwest Quadrant of the Hanford 200 West Area, HNF-SD-WM-ER-351, Rev. 1, Fluor Daniel Northwest Inc., Richland, Washington.

Brown, T. M., L. M. Sasaki, R. D. Cromar, N. G. Colton, J. L. Stroup, J. D. Franklin, and L. J. Fergestrom, 1996, Tank Characterization Report for Single-Shell Tank 241-T-109, WHC-SD-WM-ER-559, Rev. 0, Westinghouse Hanford Company, Richland Washington.

Brown, T. M., and J. D. Franklin, 1996, Tank Characterization Report for Single-Shell Tank 241-U-105, WHC-SD-WM-ER-617, Rev. 0, Westinghouse Hanford Company, Richland, Washington.

Buckingham, J. S., and W. P. Metz, 1974, Characterization of the Effects of Diatomaceous Earth Additions to Hanford Wastes, ARH-CD-222, Atlantic Richfield Hanford Company, Richland, Washington. 
Ecology, EPA, and DOE, 1994, Hanford Federal Facility Agreement and Consent Order, as amended, Washington State Department of Ecology, U.S. Environmental Protection Agency, and the U.S. Department of Energy, Olympia, Washington.

Hanlon, B. M., 1997, Waste Tank Summary Report for Month Ending February 28, 1997, HNF-EP-0182-107, Lockbeed Martin Hanford Corporation, Richland, Washington.

Hill, J. G., G. S. Anderson, and B. C. Simpson, 1995, The Sort on Radioactive Waste Type Model: A Method to Sort Single-Shell Tanks into Characteristic Groups, PNL-9814, Rev. 2, Pacific Northwest Laboratory, Richland, Washington.

Hodgson, K. M. and M. D. LeClair, 1996, Work Plan for Defining A Standard Inventory Estimate for Wastes Stored in Hanford Site Underground Tanks, WHC-SD-WM-WP-311, Rev. 1, Lockheed Hanford Company, Richland, Washington.

Horton, J. E., 1977, Physical and Chemical Characterization of Tank 116-TX, Letter to G. K. Allen, Atlantic Richfield Hanford Company, Richland, Washington.

Hu, T. A., L. C. Amato, R. T. Winward, and R. D. Cromar, 1997, Tank Characterization Report for Single-Shell Tank 241-U-102, HNF-SD-WM-ER-618, Rev. 0, Lockheed Martin Hanford Corporation, Richland, Washington.

Husa, E. I., R. E. Raymond, R. K. Welty, S. M. Griffith, B. M. Hanlon, R. R. Rios, and N. J. Vermeulen, 1993, Hanford Site Waste Storage Tank Information Notebook, WHC-EP-0625, Westinghouse Hanford Company, Richland, Washington.

Kummerer, M., 1995, Heat Removal Characteristics of Waste Storage Tanks, WHC-SD-WM-SARR-010, Rev. 1, Westinghouse Hanford Company, Richland, Washington.

Kupfer, M. J., A. L. Boldt, B. A. Higley, K. M. Hodgson, L. W. Shelton, B. C. Simpson, and R. A. Watrous (LMHC), S. L. Lambert, and D. E. Place (SESC), R. M. Orme (NHC), G. L. Borsheim (Borsheim Associates), N. G. Colton (PNNL), M. D. LeClair (SAIC), R. T. Winward (Meier Associates), and W. W. Schulz (W² S Corporation), 1997, Standard Inventories of Chemicals and Radionuclides in Hanford Site Tank Wastes, HNF-SD-WM-TI-740, Rev. 0, Lockheed Martin Hanford Corporation, Richland, Washington.

Perry, R. H., and C. H. Chilton, 1973, Chemical Engineers' Handbook, McGraw-Hill Book Company, New York, New York.

Schulz, W. W., 1980, Removal of Radionuclides from Hanford Defense Waste Solutions, RHO-SA-51, Rockwell Hanford Operations, Richland, Washington. 
HNF-SD-WM-ER-705

Revision 0

Swaney, S. L., 1993, Waste Level Discrepancies Between Manual Level Readings and

Current Waste Inventory for Single-Shell Tanks, Internal Memo 7C242-93-038 to

G. T. Frater, Westinghouse Hanford Company, Richland, Washington.

Watrous, R. A., and D. W. Wootan, 1997, Activity of Fuel Batches Processed Through Hanford Separations Plants, 1944 Through 1989, HNF-SD-WM-TI-794, Rev. 0, Lockheed Martin Hanford Corporation, Richland, Washington.

Weiss, R. L., and B. M. Mauss, 1987a, Data Transmittal Package for 241-TY-101 Waste Tank Characterization, SD-RE-TI-185, Rev. 0, Rockwell Hanford Operations, Richland Washington.

Weiss, R. L., and B. M. Mauss, 1987b, Data Transmittal Package for 241-TY-102 Waste Tank Characterization, SD-RE-TI-183, Rev. 0, Rockwell Hanford Operations, Richland Washington. 
HNF-SD-WM-ER-705

Revision 0

This page intentionally left blank. 